\title{
Dynamic Regulation of Calcium Influx by G-Proteins, Action Potential Waveform, and Neuronal Firing Frequency
}

\author{
Demian Park and Kathleen Dunlap \\ Departments of Neuroscience and Physiology, Tufts University School of Medicine, Boston, Massachusetts 02111
}

\begin{abstract}
The time course of $\mathrm{Ca}^{2+}$ channel activation and the amplitude and rate of change of $\mathrm{Ca}^{2+}$ influx are primarily controlled by membrane voltage. G-protein-coupled signaling pathways, however, modulate the efficacy of membrane voltage on channel gating. To study the interactions of membrane potential and G-proteins on $\mathrm{Ca}^{2+}$ influx in a physiological context, we have measured $\mathrm{N}$-type $\mathrm{Ca}^{2+}$ currents evoked by action potential waveforms in voltage-clamped chick dorsal root ganglion neurons. We have quantified the effect of varying action potential waveforms and frequency on the shape of $\mathrm{Ca}^{2+}$ current in the presence and absence of transmitters (GABA or norepinephrine) that inhibit $\mathrm{N}$ current. Our results demonstrate that both the profile of $\mathrm{Ca}^{2+}$ entry and the time course and magnitude of its transmitter-induced inhibition are sensitive functions of action potential waveform and frequency. Increases in action potential duration enhance total $\mathrm{Ca}^{2+}$ entry, but they also
\end{abstract}

Many physiological processes are triggered by $\mathrm{Ca}^{2+}$ influx through voltage-dependent channels, and the means by which $\mathrm{Ca}^{2+}$ signals bring about differential activation of effector responses is only partially understood. In some cases, selective activation is produced by the simple strategy of physically anchoring effectors in close proximity to a particular channel type (Jorgensen et al., 1989; Robitaille et al., 1990; Haydon et al., 1994; Gao et al., 1997). However, selectivity can also be encoded by tailoring the effector response to a specific rate or frequency of cytosolic $\mathrm{Ca}^{2+}$ concentration change (Gu and Spitzer, 1995; Dolmetsch et al., 1997; Fields et al., 1997; De Konninck and Schulman, 1998). In this case, the kinetics of $\mathrm{Ca}^{2+}$ influx (and the resultant rate of change of $\mathrm{Ca}^{2+}$ concentration) play important roles in determining the magnitude of physiological responses.

The profile of $\mathrm{Ca}^{2+}$ entry through voltage-dependent channels is shaped, in part, by the biophysical properties of the channels themselves. Channel gating (activation and inactivation) varies with changes in membrane potential waveform; thus, factors that affect action potential amplitude, duration, or frequency can produce significant alterations in the rate and time course of $\mathrm{Ca}^{2+}$ entry. In addition, $\mathrm{Ca}^{2+}$ influx can be modified by receptorand G-protein-dependent modulatory pathways that target $\mathrm{Ca}^{2+}$ channels and alter their gating properties (Dolphin, 1995; Jones and Elmslie, 1997; Dunlap and Ikeda, 1998; Ikeda and Dunlap,

\footnotetext{
Received May 14, 1998; revised June 19, 1998; accepted June 23, 1998.

This work was supported by NS16483, a Jacob Javits Award from the National Institute of Neurological Disorders and Stroke. We thank Michael Goy for critical comments on this manuscript.

Correspondence should be addressed to Kathleen Dunlap, Department of Physiology, Tufts University School of Medicine, 136 Harrison Avenue, Boston, MA 02111.

Copyright (ㄷ) 1998 Society for Neuroscience $\quad 0270-6474 / 98 / 186757-10 \$ 05.00 / 0$
}

prolong and blunt $\mathrm{Ca}^{2+}$ signals by slowing influx rate and reducing peak amplitude. Transmitter-mediated inhibition of $\mathrm{Ca}^{2+}$ entry is most robust with short-duration action potentials and decreases exponentially with increasing duration. Increases in action potential frequency promote a voltagedependent inactivation of $\mathrm{Ca}^{2+}$ influx. In channels exposed to GABA or norepinephrine, however, this inactivation is counteracted by a time- and frequency-dependent relief of modulation. Thus, multiple stimuli are integrated by $\mathrm{Ca}^{2+}$ channels, tuning the profile of influx in a changing physiological environment. Such variations are likely to be significant for the control of $\mathrm{Ca}^{2+}$-dependent cellular responses in all tissues.

Key words: $\mathrm{Ca}^{2+}$ channel; G-protein-coupled receptor; action potential; modulation; $\mathrm{Ca}^{2+}$ influx; frequency-dependent effects; G-protein
1998). Thus, a variety of parameters tailor the profile of $\mathrm{Ca}^{2+}$ influx through voltage-dependent channels and jointly regulate cellular processes in a changing physiological environment.

To gain insight into how membrane potential, channel-gating, and G-protein-dependent modulation change the profile of $\mathrm{Ca}^{2+}$ influx under varying physiological conditions, we have studied $\mathrm{Ca}^{2+}$ currents evoked by action potentials in the somata of embryonic chick dorsal root ganglion (DRG) neurons. The action potential waveform (APW) and frequency were systematically varied under voltage-clamp conditions, and the resulting effects on $\mathrm{Ca}^{2+}$ influx and its G-protein-dependent inhibition were assessed. These cells are advantageous for such studies, because they express a largely homogeneous population of $\mathrm{N}$-type $\mathrm{Ca}^{2+}$ channels (Aosaki and Kasai, 1989; Cox and Dunlap, 1992) that are inhibited by several biophysically and biochemically distinct pathways (Diversé-Pierluissi and Dunlap, 1993; Diversé-Pierluissi et al., 1995, 1997). Our results demonstrate that both the profile of $\mathrm{Ca}^{2+}$ entry and the time course and magnitude of its G-proteindependent inhibition are sensitive functions of action potential waveform and frequency. Such variations are likely to be important not only for the processing of sensory information delivered to the spinal cord via DRG neurons but also for use-dependent changes in physiological responses generated in any tissue expressing voltage-dependent $\mathrm{Ca}^{2+}$ channels.

\section{MATERIALS AND METHODS}

Cell culture. Dorsal root ganglia were dissected from single 11- to 12-dold chicken embryos (Spafas) and incubated for $30 \mathrm{~min}$ at $37^{\circ} \mathrm{C}$ in $\mathrm{Ca}^{2+}$. and $\mathrm{Mg}^{2+}$-free saline containing $0.1 \%$ collagenase A (Boehringer Mannheim, Indianapolis, IN). The $\sim 30$ ganglia were washed free of collagenase and placed into $1 \mathrm{ml}$ of culture medium consisting of DMEM supplemented with $10 \%$ heat-inactivated horse serum, $5 \%$ chicken em- 
bryo extract, $50 \mathrm{U} / \mathrm{ml}$ penicillin, $50 \mathrm{mg} / \mathrm{ml}$ streptomycin, $1 \mathrm{~mm}$ glutamine, and nerve growth factor. Ganglia were dissociated mechanically into single cells by passing them several times through a small-bore, firepolished Pasteur pipette. A small volume $(\sim 100-150 \mu \mathrm{l})$ of the singlecell suspension was applied to the center of a $35 \mathrm{~mm}$ tissue culture dish coated with rat tail collagen. After incubation for $1 \mathrm{hr}$ in a $37^{\circ} \mathrm{C} \mathrm{CO}_{2}$ incubator (to allow the cells to attach to the substrate), the dishes were flooded with $1.5 \mathrm{ml}$ of culture medium.

Electrophysiological recording and analysis. Standard tight-seal, wholecell recording methods (Hamill et al., 1981) were used to record $\mathrm{Ca}^{2+}$ currents from cells within $8 \mathrm{hr}$ of their dissociation from intact ganglia. Cells were visualized on the stage of a compound, inverted microscope, and recordings were confined to cells with short or no neurites to ensure adequate spatial control of voltage. All recordings were performed at room temperature. Current-clamp recordings of action potentials were made on cells 1-3 d in vitro, using a List Biologic (Campbell, CA) EPC-7 patch-clamp amplifier. For voltage-clamp experiments, pipettes were

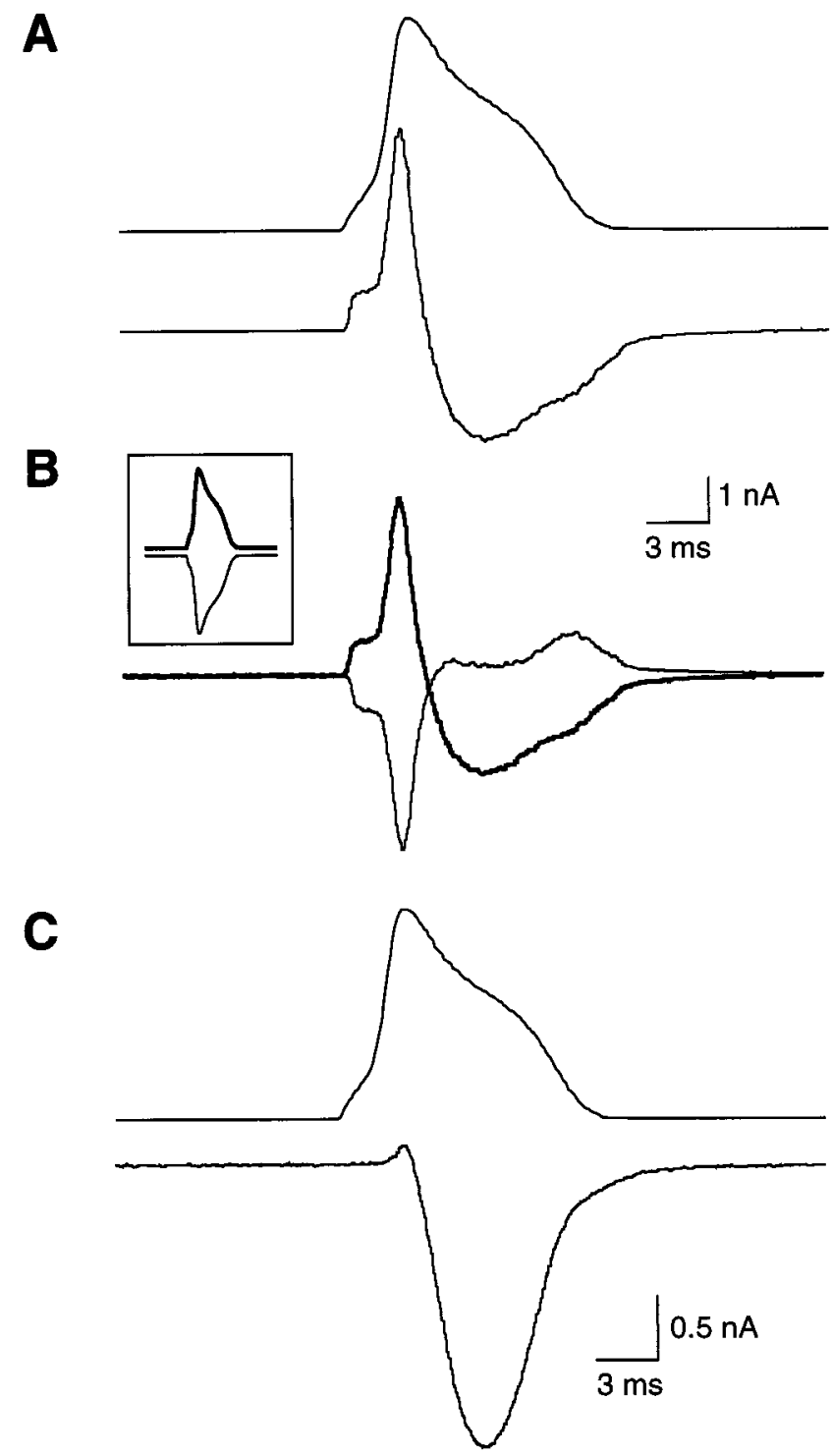

Figure 1. Isolation of APW-evoked $\mathrm{Ca}^{2+}$ current in chick DRG neurons. $A$, Total membrane current (bottom panel) evoked by an APW (top panel ) with the following properties: $20 \mathrm{mV}$ peak, $1.6 \mathrm{msec}$ rising phase, and $5.2 \mathrm{msec}$ falling phase. Holding potential, $-80 \mathrm{mV}$. B, Superimposed membrane currents produced by positive (thick line) or negative (thin line) APWs (shown in inset). C, APW (top) and voltage-dependent $\mathrm{Ca}^{2+}$ channel current (bottom) determined by the addition of the two membrane currents in $B$. Current filtered at $1 \mathrm{KHz}$.
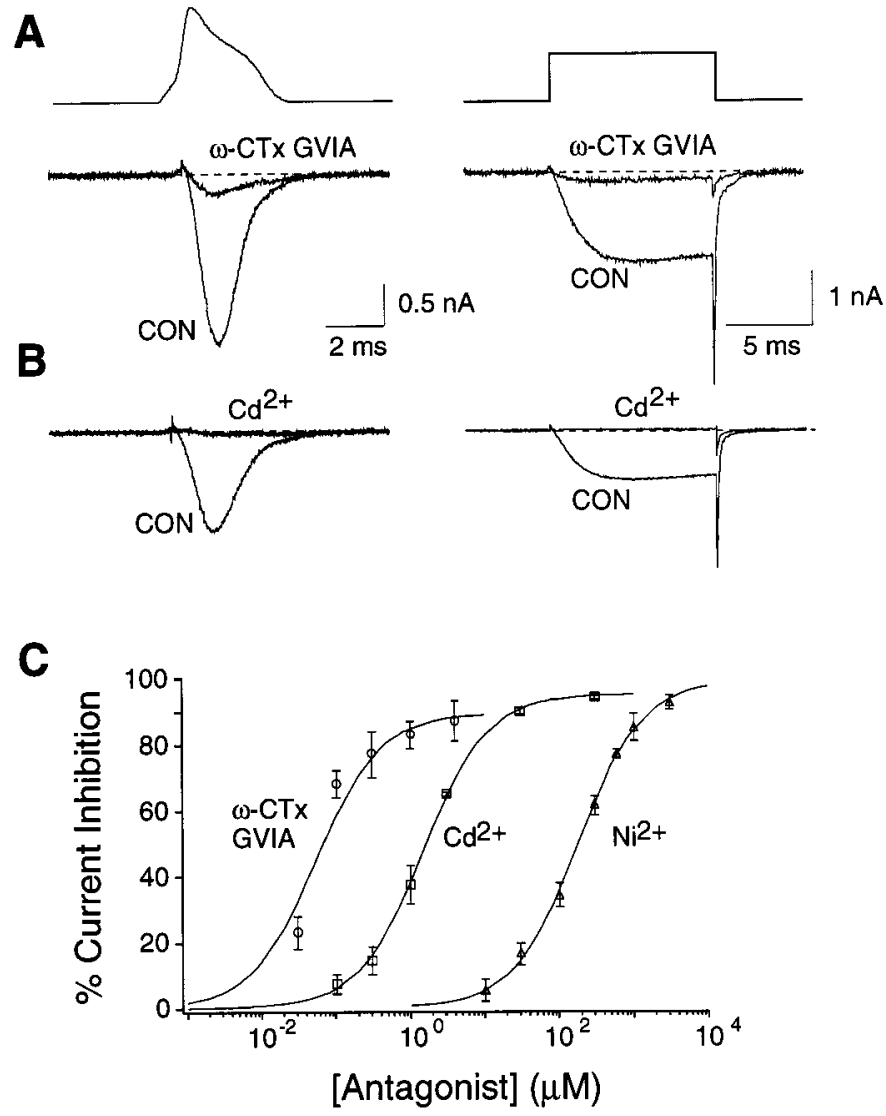

Figure 2. Pharmacological characterization of APW-evoked $\mathrm{Ca}^{2+}$ currents. $A, B$, Superimposed inward currents evoked by APWs (left) or rectangular pulses (to $0 \mathrm{mV}$, right) delivered from a holding potential of $-80 \mathrm{mV}$ before $(C O N)$, after a $3 \mathrm{~min}$ application of saturating $\omega$-conotoxin GVIA $(A)$, or during the application of $300 \mu \mathrm{M} \mathrm{Cd}^{2+}(B)$. $C$, Concentration-response relationships for $\omega$-conotoxin GVIA, $\mathrm{Cd}^{2+}$ and $\mathrm{Ni}^{2+}$ (as marked, $n=3-6$ cells per point). Smooth lines represent the least-squares fits to a single binding site equation, $\%$ inhibition $=\left(I_{\max }\right.$. $[\mathrm{Inh}]) /\left([\mathrm{Inh}]+\mathrm{IC}_{50}\right)$, where $I_{\max }$ is the maximum inhibition, [Inh] the inhibitor concentration, and $\mathrm{IC}_{50}$ the concentration of inhibitor producing half-maximal blockade. Toxin was applied for the times necessary to approach equilibrium binding; concentrations of $0.03,0.1,0.3,1.0$, and 4.0 $\mu \mathrm{M}$ were applied for $20,20,6.6 .6 .5$, and $2 \mathrm{~min}$, respectively. In cells receiving prolonged toxin applications, currents were corrected for rundown (measured in control cells from the same plating at $\sim 1 \% / \mathrm{min}$ ).

filled with a solution containing (in mM): $150 \mathrm{CsCl}, 10$ HEPES, 5 BAPTA, and $5 \mathrm{MgATP}$, and cells were bathed in $93 \mathrm{NaCl}, 50$ tetraethylammonium chloride, $1 \mathrm{CaCl}_{2}, 25 \mathrm{HEPES}, 12.5 \mathrm{NaOH}, 5 \mathrm{D}-(+)-$ glucose, and $3 \times 10^{-4}$ tetrodotoxin. For current-clamp experiments, pipettes were filled with $140 \mathrm{~K}$-aspartate, $10 \mathrm{KCl}, 5 \mathrm{MgCl}_{2}, 10 \mathrm{HEPES}$, and $0.1 \mathrm{EGTA}$, and cells were bathed in $145 \mathrm{NaCl}, 5.2 \mathrm{KCl}, 1.8 \mathrm{CaCl}_{2}$, $0.8 \mathrm{MgCl}_{2}, 10 \mathrm{HEPES}$, and $5 \mathrm{D}-(+)$-glucose. The $\mathrm{pH}$ of all solutions was 7.4.

Pipette resistances varied between 0.8 and $1.5 \mathrm{M} \Omega$ when filled with internal solution; access resistances averaged 1.6 $\pm 0.2 \mathrm{M} \Omega$ and were routinely compensated up to $>50 \%$. Potentials and currents were applied and/or recorded via an ITC-16 analog-to-digital interface (Instrutech Corp.) and a Macintosh computer running Pulse software (HEKA Electronik). For experiments using rectangular pulses, capacitive transients were canceled with the EPC-7 circuitry, currents were routinely filtered at $3 \mathrm{kHz}$, and leak currents were subtracted with a standard $\mathrm{p} / 4$ protocol using Pulse software. The command waveforms used for APW-evoked currents were taken from sharp electrode or whole-cell recordings of DRG neuron action potentials (at room temperature), using a high input impedance amplifier with a fast slew rate to avoid distortions in time course; the waveforms were then digitally altered to generate families of APWs of varied amplitude and duration. APW-evoked currents, capac- 

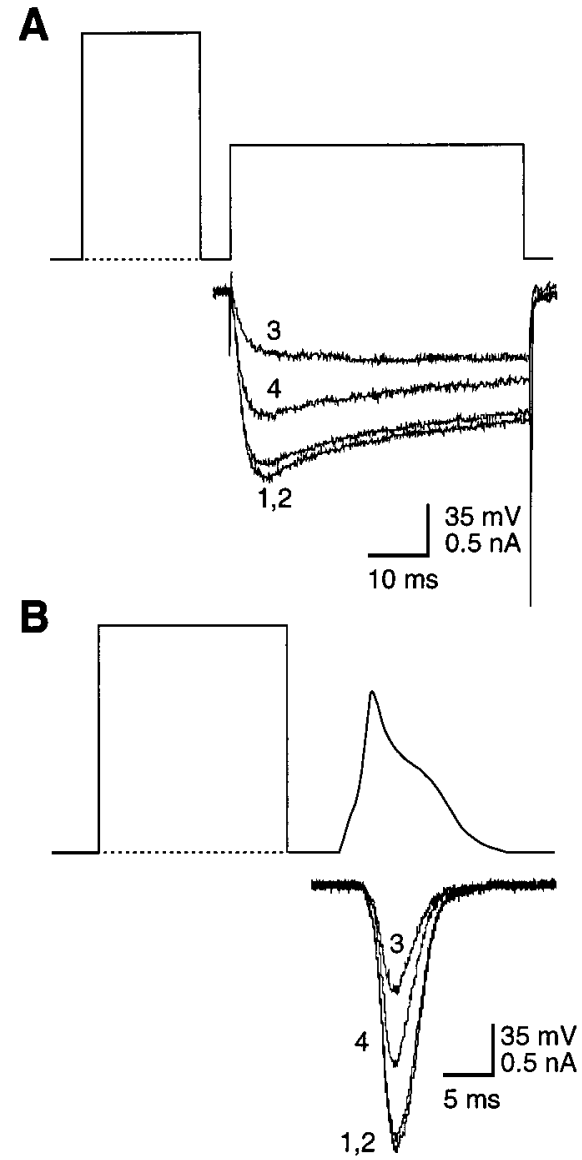

Figure 3. Voltage-dependent and -independent inhibition produced by GABA. Superimposed current traces (bottom panels) in response to 50 msec rectangular pulses $(A)$ or APWs $(B)$ without (dotted line) or with conditioning pulses $(80 \mathrm{mV}, 20 \mathrm{msec})$ preceding the test pulses by $5 \mathrm{msec}$. Holding potential, $-80 \mathrm{mV}$. Traces: 1, control; 2, control + prepulse; 3 , $100 \mu \mathrm{M}$ GABA; 4, GABA + prepulse.

itive and leakage currents were generally determined by applying a negative-going APW and subtracted from total membrane current to yield voltage-dependent $\mathrm{Ca}^{2+}$ current (Fig. 1). For certain experiments (noted in legends), $\omega$-conotoxin GVIA (applied at $1 \mu \mathrm{M}$ at the end of the recording period) was used to distinguish $\mathrm{N}$ currents from leakage and capacitive currents as well as $\mathrm{Ca}^{2+}$ currents flowing through non-N channels. Data were digitized at $40-200 \mathrm{kHz}$ (for APW-evoked currents) and $10-20 \mathrm{kHz}$ (for rectangular pulse-evoked currents). Data analysis was performed with IgorPro (Wavemetrics, Lake Oswego, OR); all averaged data are reported as means \pm SDs unless otherwise noted.

Solutions and chemicals. External solutions were exchanged rapidly by applying slight pressure to one of a linear array of polymer-coated quartz tubes (140 $\mu \mathrm{m}$ inner diameter, Polymicro Technologies, Inc.) containing normal external solution with or without drugs of interest. Solution reservoirs were positioned $\sim 30 \mathrm{~cm}$ above the microscope stage.

Stock solutions $(100-10,000 \times)$ of drugs were prepared in distilled water except bicuculline $(0.1 \mathrm{M} \mathrm{HCl}), \omega$-conotoxin GVIA (distilled water containing $1 \mathrm{mg} / \mathrm{ml}$ bovine serum albumin), and nimodipine (95\% ethanol) and stored at $-20^{\circ} \mathrm{C}$. Stock solutions of norepinephrine, however, were not stored to avoid oxidation. All working solutions (concentrations noted in text) were made by dilution from stock solutions into external saline immediately before the experiment.

\section{RESULTS}

\section{$\mathrm{N}$-type $\mathrm{Ca}^{2+}$ current evoked by action potential waveforms}

Whole-cell currents from acutely dissociated embryonic chick DRG neurons were recorded in response to APWs in the presence of $\mathrm{Na}^{+}$and $\mathrm{K}^{+}$channel blockers (Fig. 1A). Capacitative and leakage currents were estimated using a full-amplitude negative-going APW (Fig. $1 B$ ) and subtracted from total current to yield the voltage-dependent $\mathrm{Ca}^{2+}$ current. Inward $\mathrm{Ca}^{2+}$ current was preceded by a small, outward gating current (Jones et al., 1997) and reached a peak during the falling phase of the APW (Fig. $1 C$ ), as has been reported by others (Llinas et al., 1982; McCobb and Beam, 1991; Toth and Miller, 1995; Brody et al., 1997).

Pharmacological characterization of the APW-evoked current indicates a dominant component that is sensitive to $\omega$-conotoxin GVIA (the irreversible $\mathrm{N}$ channel antagonist). This toxin produced an average maximal inhibition of $87 \pm 6 \%$ (Fig. $2 A, C$ ) and a concentration-response relationship that can be well fitted with a single-binding site isotherm with half-maximal inhibition at 53 nм (Fig. 2C).

No reversal of $\omega$-CTx GVIA-induced inhibition was observed during 60 min washout of toxin (data not shown). It has been reported that L-type currents in chick DRG neurons are blocked reversibly by $\omega$-CTx GVIA (Aosaki and Kasai, 1989); the irreversibility of toxin blockade in our experiments, therefore, sug-
A
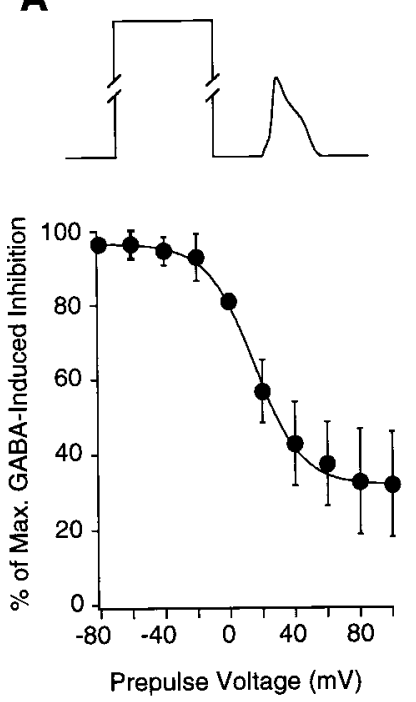

B
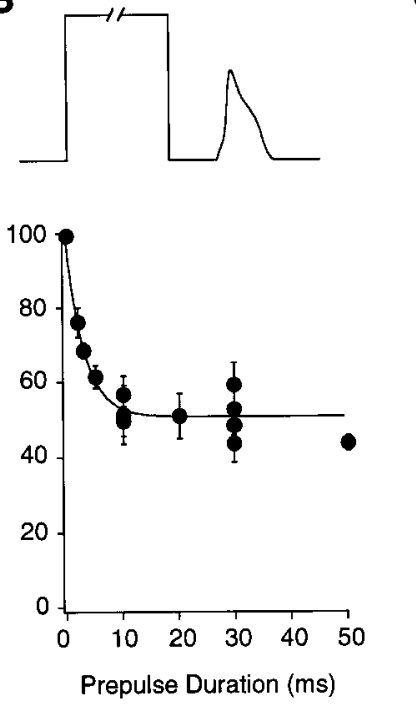

C
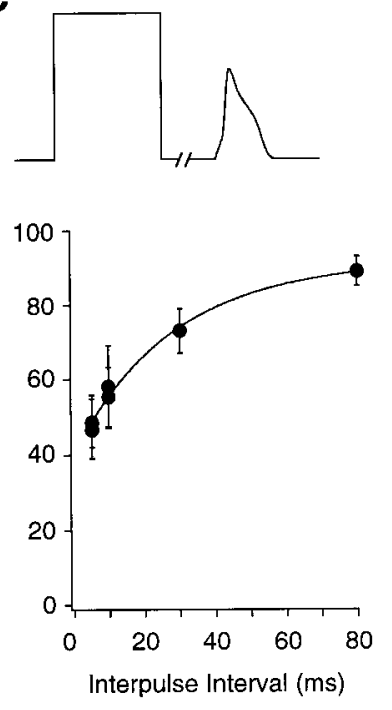

Figure 4. Quantitation of voltagedependent inhibition. GABA-induced inhibition of APW-evoked current plotted as a function of prepulse amplitude $(A)$, duration $(B)$, or interpulse interval $(C)$. Voltage commands are shown in top panels. Fixed prepulse parameters were as follows: $A, 20 \mathrm{msec}$ duration, 5 msec interval; $B, 80 \mathrm{mV}$ amplitude, 5 msec interval; and $C, 80 \mathrm{mV}$ amplitude, $20 \mathrm{msec}$ duration. Data points in all panels represent means of measurements from four to six cells; lines drawn through data points represent least squares fits to Boltzmann function $\left(V^{1 / 2}\right.$ $=15 \mathrm{mV} ;$ slope $=14 \mathrm{mV})(A)$ or single exponential functions $(B, C ; \tau=3.3$ $\mathrm{msec}$ for $B$ and $28 \mathrm{msec}$ for $C$ ). 

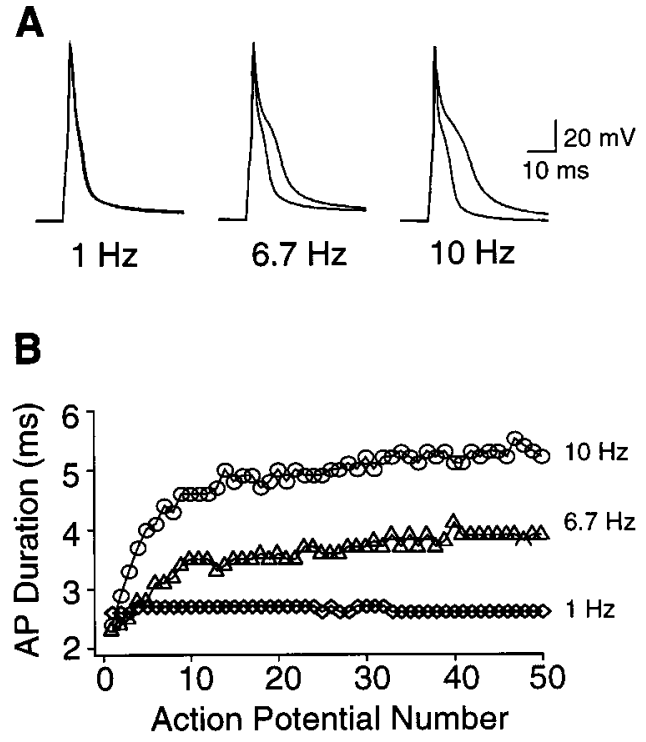

Figure 5. Frequency-dependent action potential broadening. A, Action potentials recorded from a DRG neuron under current clamp. Current pulses (1 nA, $3 \mathrm{msec})$ were applied at 1, 3.3, 6.7, and $10 \mathrm{~Hz}$ (left to right); the 1st and 50th action potentials are shown superimposed. B, Action potential duration as a function of action potential number, illustrating the progression of frequency-dependent increases in duration. Data points represent means of measurements from three to five cells. Error bars are omitted for clarity.

gests the absence of $\mathrm{L}$ channels under our recording conditions. To further confirm the absence of $\mathrm{L}$ channels, we used the dihydropyridine antagonist, nimodipine, which maximally inhibits $\mathrm{L}$ channel current at a concentration of $100 \mathrm{~nm}$ (Triggle and Janis, 1987). When applied at $5 \mu \mathrm{M}$, nimodipine was without effect on seven of seven neurons tested (mean current amplitudes, $2.35 \pm 0.48$ and $2.33 \pm 0.46 \mathrm{nA}$ without and with nimodipine, respectively).

Low-voltage-activated (LVA) currents have been shown previously to provide substantial $\mathrm{Ca}^{2+}$ influx during APWs in chick DRG neurons at early stages of development (McCobb and Beam, 1991). Both biophysical and pharmacological means were used to test for the presence of LVA current under our recording conditions. Little rapidly inactivating current (characteristic of LVA channels) was observed with step depolarizations (Fig. $2 A$, right), suggesting that, if present, the LVA current component was small. To determine whether a small component might be accentuated by APW commands, we exploited the observation that LVA currents are more sensitive to $\mathrm{Ni}^{2+}$ than to $\mathrm{Cd}^{2+}$, whereas HVA channels have the opposite sensitivity (Carbone and Lux, 1984; Fox et al., 1987; Narahashi et al., 1987). We recorded $\mathrm{Ca}^{2+}$ currents from several cells in response to APWs during application of a range of $\mathrm{Cd}^{2+}$ (Fig. $2 B, C$ ) or $\mathrm{Ni}^{2+}$ (Fig. 2C) concentrations. The $\mathrm{IC}_{50}$ for $\mathrm{Ni}^{2+}$ was $177 \mu \mathrm{M}, \sim 100$-fold higher than that for $\mathrm{Cd}^{2+}(1.5 \mu \mathrm{M})$, indicating a predominance of HVA current. Data were well fitted with a single-binding site equation, suggesting that the current did not contain two components with significantly different sensitivities to $\mathrm{Ni}^{2+}$ and $\mathrm{Cd}^{2+}$ (Fig. 2C).

APW-evoked $\mathrm{Ca}^{2+}$ currents in our preparation are, thus, largely HVA- and N-type, consistent with results from rectangular pulse experiments (Cox and Dunlap, 1992). The small current that is insensitive to $\omega$-CTx GVIA and nimodipine was not blocked by $1 \mu \mathrm{M} \omega$-agatoxin IVA, the P/Q channel antagonist (M.
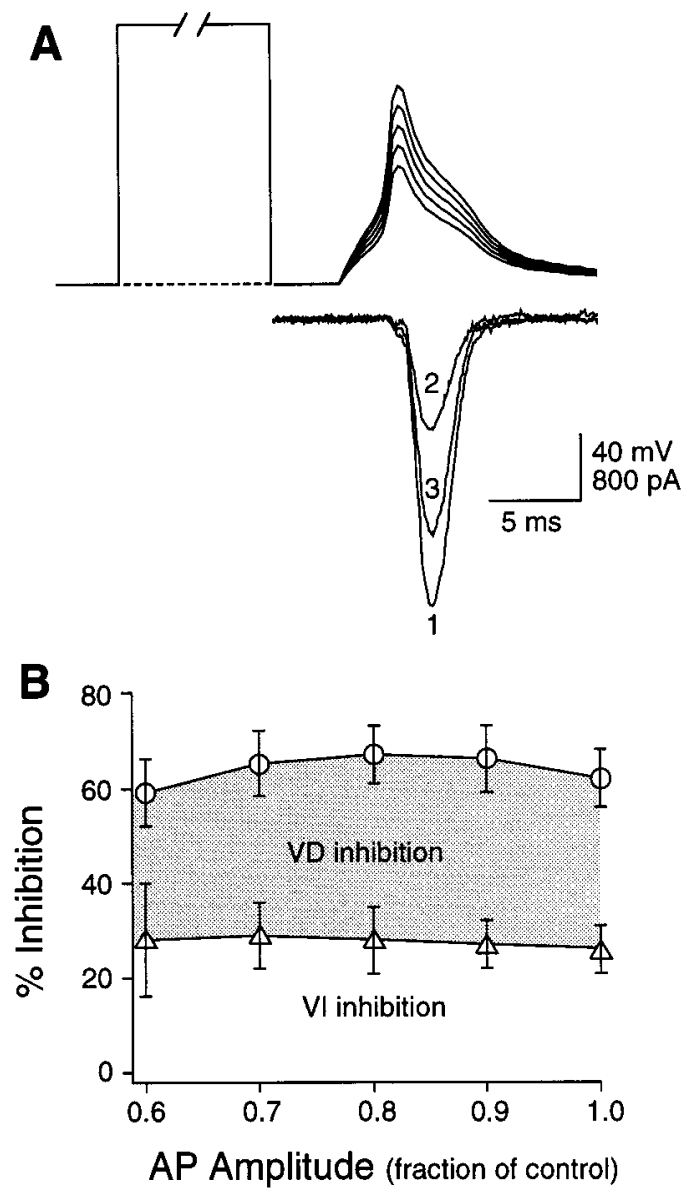

Figure 6. APW amplitude does not affect GABA-induced inhibition. $A$, APWs (top panel) used to evoke $\mathrm{Ca}^{2+}$ currents (amplitudes varied between 44 and $-6 \mathrm{mV}$, duration constant at $2.6 \mathrm{msec})$; prepulse $(80 \mathrm{mV}$, $20 \mathrm{msec}, 5 \mathrm{msec}$ interval) used to separate VD from VI inhibition. Bottom panel, Effect of $100 \mu \mathrm{M}$ GABA without (2) and with (3) prepulse on currents in response to $44 \mathrm{mV}$ APW; 1 , control. $B$, Plot of total inhibition $(\bigcirc)$ and inhibition remaining after prepulse $(\triangle)$. The shaded area represents the VD component of inhibition. Data points represent means \pm SDs of measurements from four cells.

AtKisson and K. Dunlap, unpublished observations) and, therefore, most resembles R-type current described in other preparations (Mintz et al., 1992).

\section{GABA inhibits APW-evoked $\mathbf{C a}^{2+}$ current}

Several transmitters, including GABA and norepinephrine (NE), inhibit N-type $\mathrm{Ca}^{2+}$ channels in chick DRG neurons; each transmitter can act via multiple G-protein pathways (Cox and Dunlap, 1992; Diversé-Pierluissi et al., 1995, 1997). One pathway, accounting for a portion of the inhibition, is mediated by a mechanism that (1) produces a slowing in the current activation kinetics; and (2) is attenuated by previous depolarization to positive potentials (Bean, 1989; Elmslie et al., 1990; Luebke and Dunlap, 1994). The contribution of this pathway [termed voltage-dependent (VD) modulation] can be estimated using a two-pulse paradigm (Jones and Elmslie, 1997) in which a conditioning prepulse reverses the transmitter-induced inhibition and returns activation kinetics to control rates (Fig. 3A). Not all inhibition is voltage-dependent in chick DRG neurons, however (Grassi and Lux, 1989; DiverséPierluissi and Dunlap, 1993; Luebke and Dunlap, 1994). The magnitude of the voltage-independent (VI) component can be 


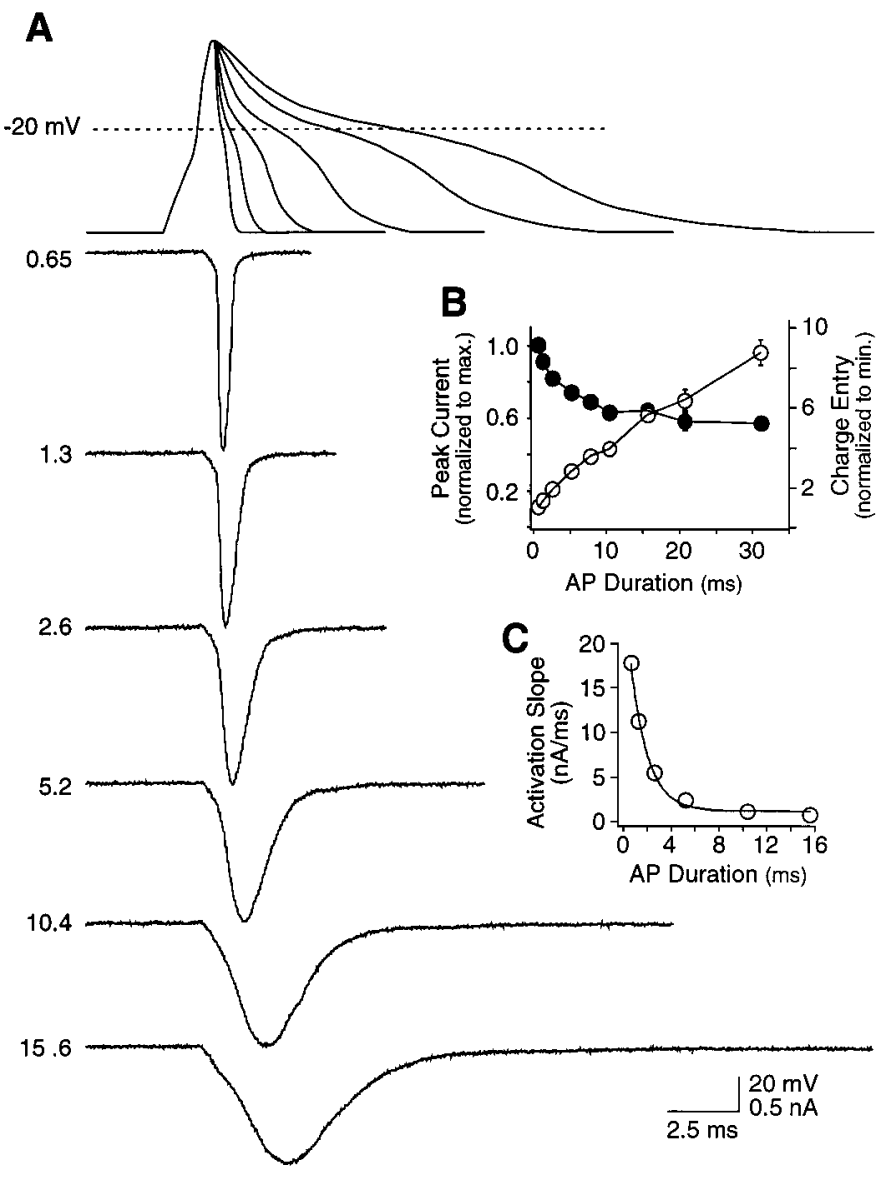

Figure 7. Current waveform changes with action potential duration. $A$, Currents evoked by varying action potential duration (in milliseconds, noted to the left of each trace). APWs are illustrated in the top panel (amplitude, $33 \mathrm{mV}$; rising phase, $3.2 \mathrm{msec}$ ). B, Peak current (०) and total charge entry (or integral of $\mathrm{Ca}^{2+}$ current, $\bigcirc$ ) plotted as a function of action potential duration. Data points represent means \pm SDs of measurements from five to eight cells. $C, \mathrm{Ca}^{2+}$ current activation rate plotted as a function of action potential duration; data are measurements from a single cell.

estimated as that fraction of inhibition remaining after conditioning prepulses; V I inhibition varies among cells and, in exceptional cases, represents virtually $100 \%$ of the transmitter effect, demonstrated by the absence of kinetic slowing and prepulse-induced facilitation (Luebke and Dunlap, 1994).

Previous studies have evaluated transmitter-mediated VD and VI inhibition of $\mathrm{Ca}^{2+}$ currents evoked with rectangular voltage steps (Fig. 3A), but little is known about the effects of these inhibitory processes on currents evoked by the more physiological APW. GABA $(100 \mu \mathrm{M})$ produced an average $50 \pm 8 \%$ inhibition of peak current $(n=17)$ evoked by APWs of $5.2 \mathrm{msec}$ duration (Fig. 3). The kinetics of the APW-evoked current in the presence of transmitter were unchanged (Fig. $3 B$ ), in contrast to the slowing of current activation observed with rectangular pulses (Fig. $3 A$ ). Given, however, that slowed gating is a protracted event (with a time constant of $10-15 \mathrm{msec}$ ), it would be difficult to observe such effects during the brief activation phases of APWevoked currents. The presence of VD inhibition can, however, be established using the two-pulse paradigm (Fig. $3 B$ ). When the test APW is preceded by $5 \mathrm{msec}$ with a $20 \mathrm{msec}$ conditioning depolarization to $80 \mathrm{mV}$, the inhibition produced by GABA is reduced to $20 \pm 5 \%(n=6)$; that is, at least $60 \%$ of the modulatory effect of GABA is voltage-dependent. The prepulse produced little or no effect on unmodulated currents (Fig. $3 A, B$ ).

To establish optimal conditions for quantitating the proportions of VD and VI inhibition by transmitters, we varied the prepulse amplitude and duration and the interpulse interval and measured their effects on GABA-induced inhibition. With a prepulse duration of $20 \mathrm{msec}$ and an interpulse interval of $5 \mathrm{msec}$, variations in prepulse amplitude from -80 to $100 \mathrm{mV}$ produced a relief of GABA-induced inhibition that increased with increasing prepulse amplitude. Maximal relief of inhibition was achieved with a prepulse to $80 \mathrm{mV}$, and the half-maximal effect occurred at $15 \mathrm{mV}$ (Fig. 4A). Using a fixed amplitude prepulse to $80 \mathrm{mV}$ and a $5 \mathrm{msec}$ interval, increasing prepulse duration attenuated GABA-induced inhibition; the amount of inhibition decreased exponentially during the first $15-20 \mathrm{msec}$ of prepulse $(\tau=3.3$ msec) (Fig. 4B).

Prepulses to $80 \mathrm{mV}$ for $20 \mathrm{msec}$ were then used to examine the effect of increasing the interpulse interval from 5 to 80 msec. GABA-induced inhibition was relieved more effectively with shorter intervals; the relationship could be well fit to a single exponential function with a time constant of $28 \mathrm{msec}$ (Fig. 4C). Maximal effects of prepulse were actually observed with no interpulse interval; however, under these conditions, the evaluation of APW-evoked currents was hampered by the tail currents flowing during prepulse repolarization. Our routine analysis, therefore, used a $5 \mathrm{msec}$ interpulse interval, recognizing that, under such conditions, the VD component is underestimated by $\sim 15 \%$.

\section{Frequency-dependent changes in action potential shape}

Given that a portion of transmitter-induced inhibition of $\mathrm{N}$ channels is sensitive to voltages and durations typically achieved by action potentials under normal physiological conditions, we explored whether the effects of transmitters vary with changes in action potential waveform and frequency. Initial experiments explored the use-dependent changes in DRG neuron action potentials that can occur under normal physiological conditions in the absence of transmitter. At modest firing frequencies (from 1 to $10 \mathrm{~Hz}$ ), the amplitude decreased slightly and the duration increased significantly over the first 50 action potentials (Fig. $5 A$ ) - effects that were accentuated at higher frequencies (Fig. $5 B$ ). Given that such changes are possible, we systematically varied action potential shape and frequency to study their effects on VD and VI inhibition produced by transmitters.

\section{Inhibition of $\mathrm{Ca}^{2+}$ current as a function of action potential shape}

To test for an effect of action potential amplitude on transmitterinduced inhibition, the peak of the command APW was varied from 44 to $-6 \mathrm{mV}$ in the absence or presence of $100 \mu \mathrm{M}$ GABA. $\mathrm{VD}$ and VI inhibition were separated using the standard prepulse paradigm outlined above $(80 \mathrm{mV}, 20 \mathrm{msec}, 5 \mathrm{msec}$ interval $)$. As shown in Figure 6, decreasing action potential amplitude had no significant effect on GABA-induced inhibition. This is, perhaps, not surprising: although the amplitude of the action potential was varied over a voltage range that affects GABA-mediated inhibition (Fig. $4 A$ ), the time over which the membrane is exposed to 
Figure 8. GABA-mediated inhibition changes with action potential duration. Currents evoked by APWs of varying duration (in milliseconds, noted to the left of each trace) in control (largest currents) or during application of $100 \mu \mathrm{M}$ GABA (smallest currents). $B$, Total GABAinduced inhibition $(O)$ of peak $\mathrm{Ca}^{2+}$ current or inhibition in presence of prepulse $(\square)-+80 \mathrm{mV}, 20 \mathrm{msec}, 5$ msec interval-plotted as a function of APW duration. The line through $\bigcirc$ represents least squares fit to single exponential $(\tau=13 \mathrm{msec})$; through $\square$ is a straight line. Data points represent means \pm SDs of measurements from five to eight cells. The shaded area represents the VD component of inhibition.

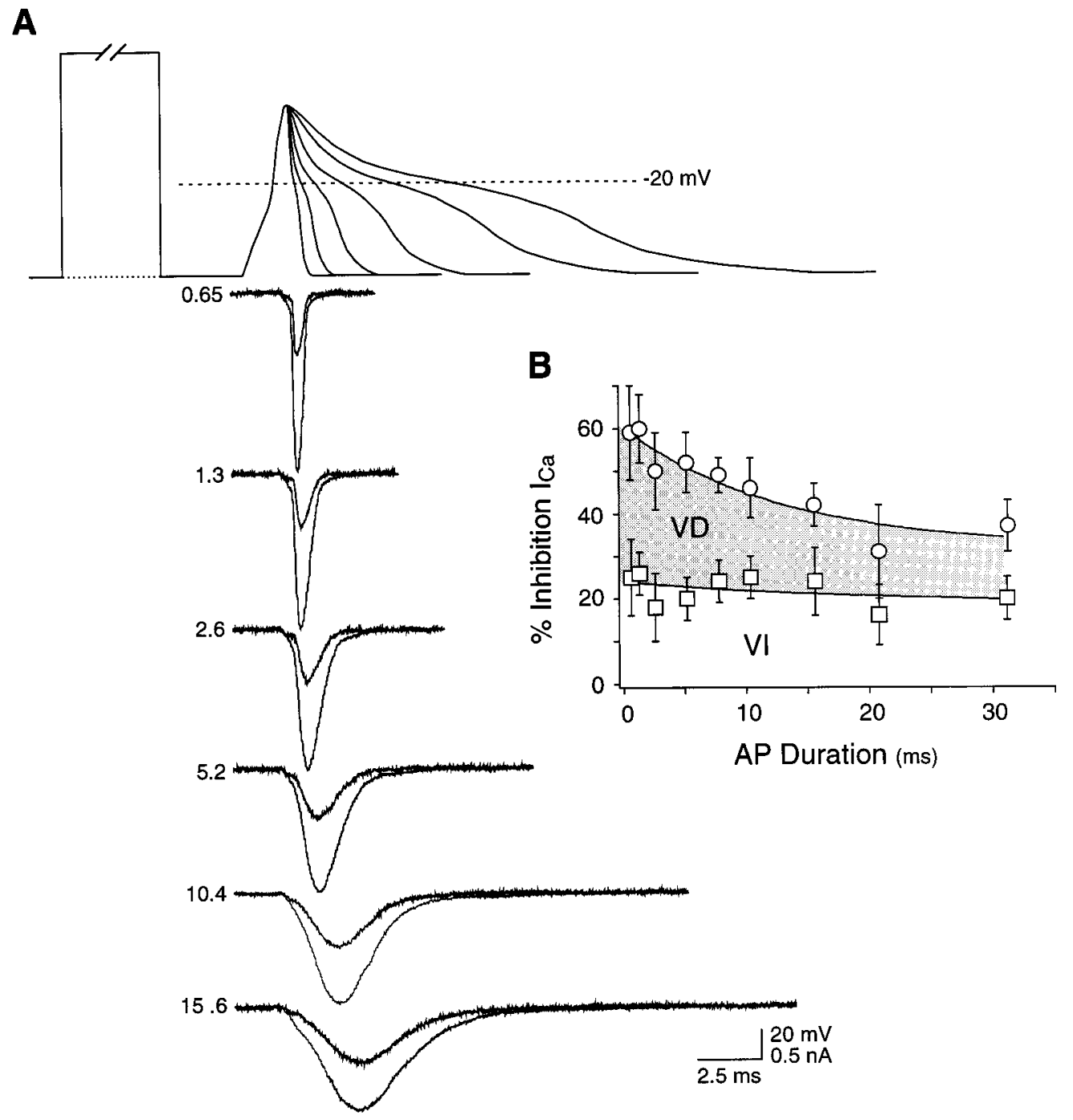

\section{A}

such peak depolarizations $(<1 \mathrm{msec})$ is too brief to promote significant relief of inhibition (Fig. 4B).

In contrast, changes in action potential duration effectively altered GABA-induced inhibition. The duration (from peak to half amplitude on the falling phase) was varied from 0.65 to 31.2 msec (keeping amplitude constant at $33 \mathrm{mV}$ ). Longer-duration APWs evoked lower-amplitude currents that activated more slowly (Fig. 7A). Peak current decreased approximately exponentially with increases in APW duration, whereas total charge entry increased approximately linearly (Fig. 7B). Application of $100 \mu \mathrm{M}$ GABA decreased $\mathrm{Ca}^{2+}$ currents evoked by all APWs, but the total inhibition varied inversely with duration (Fig. 8A,B), a relationship that could be well fitted with a single exponential function $(\tau=13 \mathrm{msec})$. Conditioning prepulses were used to isolate the VI component of inhibition and demonstrate that the APW duration-dependent decrease in inhibition was associated exclusively with the VD component (Fig. 8B). Plotted in Figure 8 is peak current; a similar relationship is seen for $\mathrm{Ca}^{2+}$ charge entry (data not shown).

\section{AP train-dependent relief of $\mathrm{Ca}^{2+}$ current inhibition}

Because transmitter-induced inhibition varies during the time course of a single action potential (Fig. 8), and the potentialdependent relief of inhibition persists for some time after mem- brane repolarization (Fig. $4 C$ ), we explored how $\mathrm{Ca}^{2+}$ currents and their modulation were affected by trains of APWs delivered at frequencies within the range of sensory neuron firing rates observed in vivo (Fitzgerald, 1987).

\section{$\mathrm{Ca}^{2+}$ currents inactivate during train of action potentials}

Under control conditions, peak $\mathrm{Ca}^{2+}$ current decreased steadily throughout action potential trains and was reduced $\sim 10 \%$ by 15 action potentials delivered at $73 \mathrm{~Hz}$ (Fig. 9). This phenomenon, termed "preferential closed-state inactivation" by Patil et al. (1998), results from a voltage-dependent inactivation mechanism that proceeds after repolarization and accumulates during the interspike interval.

The presence of closed-state inactivation complicates measurement of train-dependent effects on transmitter-mediated inhibition of $\mathrm{Ca}^{2+}$ channels. Consistent with Patil et al. (1998), however, we found that the rate of inactivation is significantly slowed at negative potentials; repolarization of the interspike potential to less than $-120 \mathrm{mV}$ largely eliminated closed-state inactivation of control currents during the trains (Fig. 9B). The effect of action potential trains on transmitter-mediated inhibition of $\mathrm{Ca}^{2+}$ channels could, therefore, be tested in the absence of inactivation by using trains of stimuli with interspike potentials of less than $-120 \mathrm{mV}$. 
A
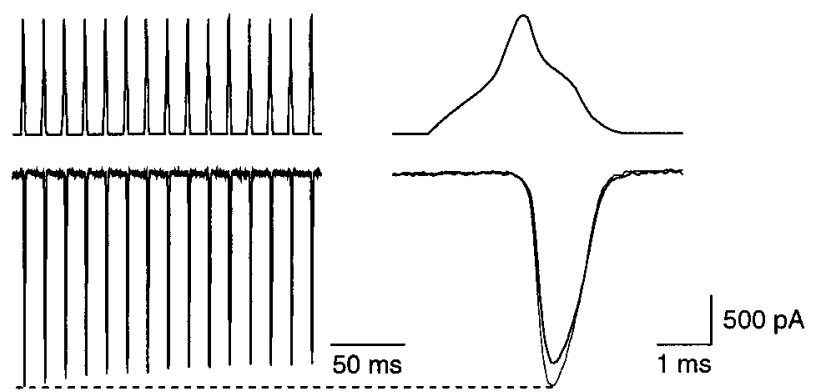

B

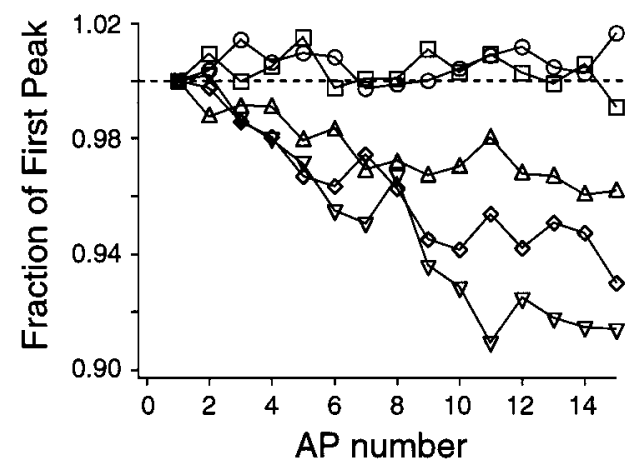

Figure 9. Inactivation of $\mathrm{Ca}^{2+}$ currents evoked by trains of APWs. $A$, $\mathrm{Ca}^{2+}$ currents (bottom panel) evoked by a train of 15 APWs (top panel) delivered at $73 \mathrm{~Hz}$ (averages of 5 sweeps). Right panels show superimposed first (thinner lines) and last (thicker lines) traces on expanded time scale. The horizontal dashed line marks amplitude of first APW-evoked current. Leakage subtraction performed using currents remaining after application of $1 \mu \mathrm{M} \omega$-conotoxin GVIA. $B$, Peak current (normalized to first current trace in train) as a function of the position in trains in which the interspike potential was $-60(\nabla),-80(\diamond),-100(\triangle),-120(\square)$, and $-140(\bigcirc) \mathrm{mV}$. Data are average values from nine cells each; error bars are omitted for clarity.

\section{Train-dependent relief of transmitter action}

Experiments used both GABA and NE. Previous results have demonstrated that GABA evokes VD inhibition more strongly than does NE (Diversé-Pierluissi and Dunlap, 1993), and the present results confirm this. Of nine cells tested with $100 \mu \mathrm{M}$ GABA, all showed VD inhibition (averaging $44.8 \pm 5.3 \%$ of a total $67 \%$ inhibition). Likewise, eight of the nine demonstrated robust relief of inhibition (or facilitation) during a stimulus train; responses varied between 16 and $37 \%$ in the eight cells, with an average $21.4 \%$ relief of inhibition produced by 15 APWs (Fig. 10).

The facilitation of modulated current during trains of APWs likely reflects a partial reversal of transmitter- or G-proteinmediated VD inhibition. To ensure that the facilitation was not a product simply of smaller amplitude $\mathrm{Ca}^{2+}$ currents flowing through modulated channels, $\mathrm{Cd}^{2+}(3 \mu \mathrm{M})$ was used to reduced the currents to a level similar to that produced by GABA), and the same train of APWs was applied. $\mathrm{Cd}^{2+}$, at $3 \mu \mathrm{m}$, inhibited currents by $58 \%$, and during a train, the currents inactivated at rates indistinguishable from control currents, with no traindependent facilitation (data not shown). This supports the conclusion that the facilitation of modulated currents during stimulus trains reflects the relief of transmitter-induced VD inhibition.

This conclusion was further tested using NE, which, unlike
A
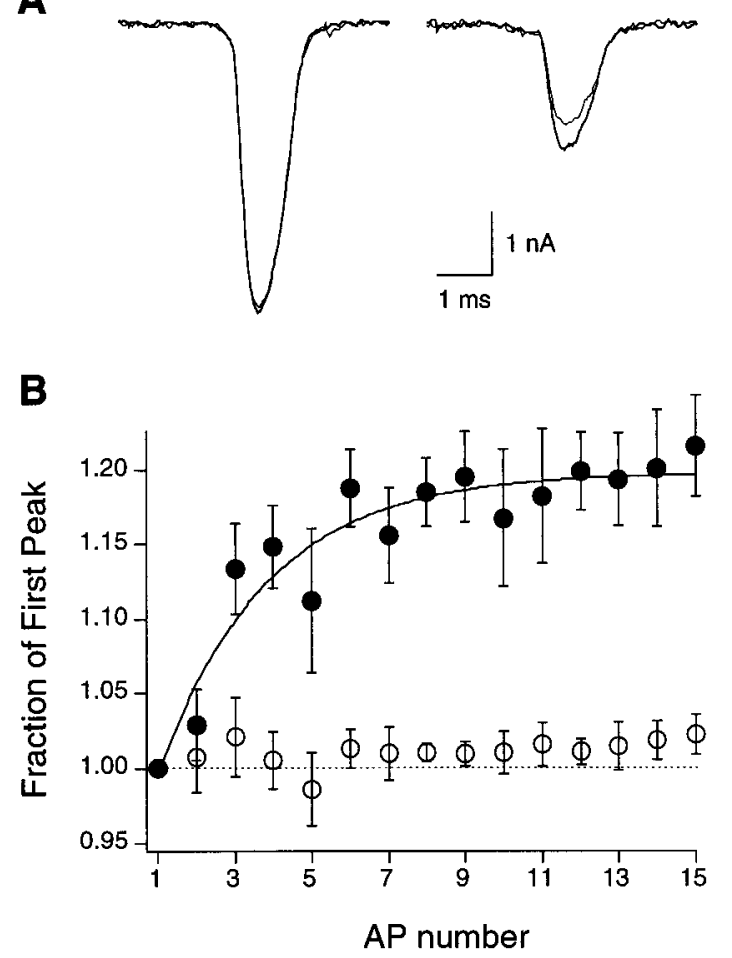

Figure 10. AP train-dependent facilitation of GABA-inhibited $\mathrm{Ca}^{2+}$ currents. $A$, Current traces evoked by trains of 15 APWs $(73 \mathrm{~Hz})$ with an interspike potential of $-140 \mathrm{mV}$; shown superimposed are currents (averaged individual traces from eight cells) evoked by the 1st (thin line) and 15th (thick line) APWs delivered before (left) or during (right) application of $100 \mu \mathrm{M}$ GABA. $B$, Relative peak amplitudes of currents (normalized to first current peak) as a function of position in APW train. $\bigcirc$, Control current; $\bullet$, modulated current. Data are means \pm SEs for measurements on eight cells.

GABA, produces a wide range of inhibition with a variable ratio of VD and VI components (Diversé-Pierluissi and Dunlap, 1993; Luebke and Dunlap, 1994). A mean $23 \pm 10 \%$ VD inhibition was evoked by $100 \mu \mathrm{M}$ NE in 7 of 13 cells, whereas the remainder showed VI inhibition only. Train-dependent relief of inhibition was moderate (mean, $9.7 \pm 6.2 \%$ ) and confined only to cells in which NE evoked a VD component of inhibition (Fig. 11). These results demonstrate that facilitation of modulated $\mathrm{Ca}^{2+}$ current during the AP train results from a reversal of VD inhibition rather than from an effect on closed-state inactivation. Consistent with this, we found a tight correlation between the magnitude of VD inhibition produced by the transmitters and the amount of facilitation evoked during action potential trains (Fig. 12).

\section{Frequency-dependent relief of transmitter action}

Because facilitation subsides with time after prepulses (Fig. 4C), train-dependent relief of inhibition should be less effective with lower-frequency trains. This is the case (Fig. 13). Trains of 15 stimuli delivered at $45 \mathrm{~Hz}$ (20 msec interval) were only half as effective at relieving GABA-induced inhibition as were trains delivered at $143 \mathrm{~Hz}$ (5 msec interval).

\section{DISCUSSION}

We have studied the transmitter-mediated modulation of N-type $\mathrm{Ca}^{2+}$ currents evoked by action potential waveforms and demonstrate that the extent and time course of inhibition produced by 

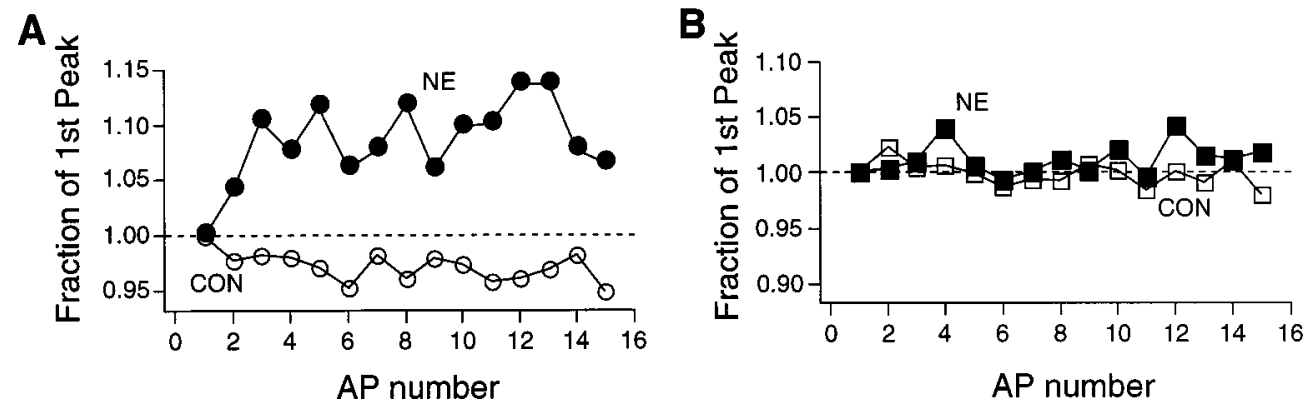

Figure 11. Train-dependent facilitation of NE-inhibited $\mathrm{Ca}^{2+}$ currents. Currents evoked by trains of 15 APWs ( $73 \mathrm{~Hz}$; interspike potential, $-120 \mathrm{mV}$ ) were normalized to peak of first current in train and plotted as a function of position in an APW train before $(C O N)$ or during $(N E)$ application of $100 \mu \mathrm{M}$ NE. $A$, Data from a cell with $33 \%$ VD inhibition. $B$, Data from a cell with $4 \%$ VD inhibition.
GABA and NE depend on both the shape of the action potential and the frequency of firing.

Changes in action potential waveform, such as those seen in our studies, are known to occur under a variety of physiological conditions. Developmental changes in duration can be particularly dramatic; in frog embryos, for example, the duration of $\mathrm{Ca}^{2+}$-dependent action potentials in spinal neurons decreases from $>1$ sec to 1-2 msec over the course of several hours (Spitzer, 1984). In mammalian and avian DRG neurons, action potential waveforms also vary during development (Spitzer, 1984), are altered by growth factors (Chalazonitis et al., 1987), and differ among groups of sensory afferents responding to different stimulus modalities (Koerber et al., 1995). Acutely, many transmitters are known to reduce action potential duration through inhibition of $\mathrm{Ca}^{2+}$ channel and/or enhancement of $\mathrm{K}^{+}$channel activity (Gage, 1992; Dolphin, 1995), and during trains of stimuli, action potential duration commonly increases twofold or more, often caused by a frequency-dependent inactivation of $\mathrm{K}^{+}$channels (Aldrich et al., 1979; Jackson et al., 1991; Ma and Koester, 1996). Thus, changes in action potential waveform are ubiquitous and physiologically significant.

Increasing action potential duration generally results in an overall increase in $\mathrm{Ca}^{2+}$ influx, but if the change in duration is large enough, the rate of $\mathrm{Ca}^{2+}$ entry is slowed and peak influx is

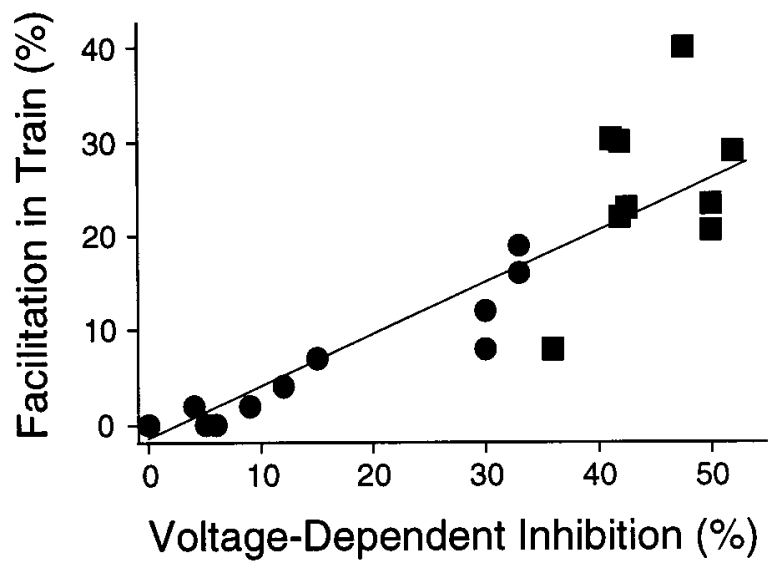

Figure 12. Train-dependent facilitation requires VD modulation. The facilitation of currents evoked by a train of 15 APWs $(73 \mathrm{~Hz}$; interspike potential, -120 or $-140 \mathrm{mV}$ ) plotted as a function of the magnitude of VD inhibition produced by $100 \mu \mathrm{M} \mathrm{NE}(\bullet)$ or GABA $(\mathbf{\square})$. The percentage of facilitation was calculated by $\%$ facilitation $=100-\left[\left(p_{15} / p_{1}\right) \cdot\right.$ $100]$, where $p_{15}$ and $p_{1}$ are the peak amplitudes of currents evoked by the 1st and 15th APWs, respectively. The percentage of VD inhibition was calculated as $\% \mathrm{VD}$ inh $=\left[\left(1-I_{3} / I_{1}\right)-\left(1-I_{4} / I_{2}\right)\right] \cdot 100$, where $I_{1}, I_{2}$, $I_{3}$, and $I_{4}$ are peak currents evoked by single APWs in control, control + prepulse, GABA, and GABA + prepulse, respectively. The line represents linear regression fit; correlation coefficient, 0.95 . reduced, as confirmed by the data in Figure 7. Such alterations in the profile of $\mathrm{Ca}^{2+}$ influx have significant physiological consequences. Both the rate and the absolute amplitude of $\mathrm{Ca}^{2+}$ influx play a role in determining the magnitude of $\mathrm{Ca}^{2+}$-dependent responses in nerve cell bodies (such as enzyme activation or gene transcription) or in nerve terminals (such as exocytosis) (Spencer et al., 1989; Ghosh et al., 1994; Hsu et al., 1996; Dolmetsch et al., 1997; Fields et al., 1997; De Konninck and Schulman, 1998). In chick DRG neurons, the rate of $\mathrm{Ca}^{2+}$ entry varies exponentially with action potential duration (dropping $\sim \mathrm{e}$-fold with each $\mathrm{msec}$ increase in duration, Fig. $7 C$ ). Similar reductions in the rate of change in intracellular $\mathrm{Ca}^{2+}$ at the squid giant synapse (keeping the maximum amplitude constant) produces an approximate threefold decrease in transmitter release (Hsu et al., 1996). Simultaneous reductions in amplitude would further magnify effects of changing action potential duration, because exocytosis (and many other $\mathrm{Ca}^{2+}$-dependent physiological processes) varies as a power function of $\mathrm{Ca}^{2+}$ concentration.

Frequency-dependent changes in APW and associated $\mathrm{Ca}^{2+}$ influx are further sculpted by transmitters and G-proteins. GABA reduces peak $\mathrm{Ca}^{2+}$ current in chick DRG neurons by an average of $60 \%$ for $0.65 \mathrm{msec}$ APWs, and as action potential duration increases, GABA-induced inhibition drops exponentially, with a time constant of $13 \mathrm{msec}$. In addition, for any given duration action potential, GABA reduces the rate of $\mathrm{Ca}^{2+}$ influx by twofold to threefold compared with controls. This combination of GABA effects would greatly reduce the overall rise in intracellular $\mathrm{Ca}^{2+}$ and substantially inhibit $\mathrm{Ca}^{2+}$-dependent effector

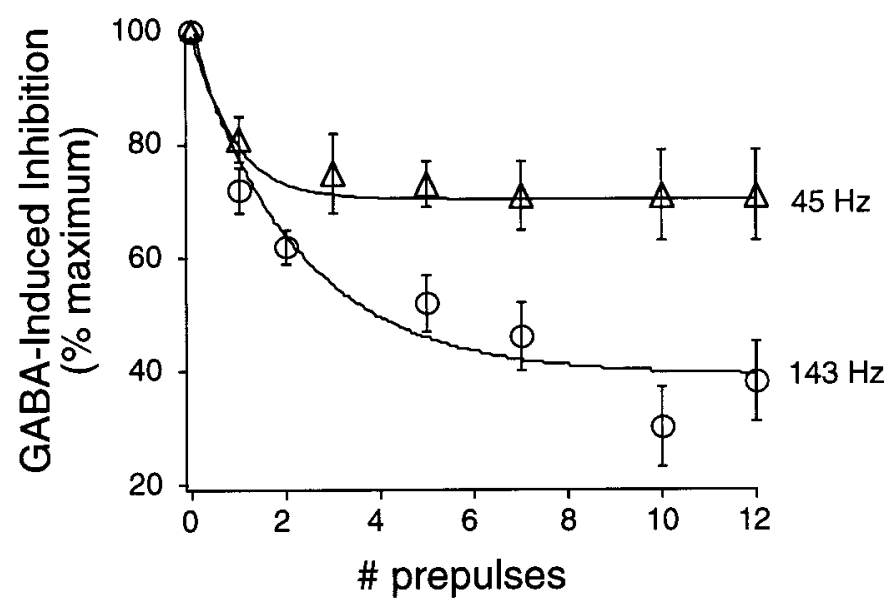

Figure 13. Frequency-dependent relief of GABA-mediated inhibition. Maximum inhibition produced by $100 \mu \mathrm{M}$ GABA plotted as a function of the number of prepulses $(80 \mathrm{mV}, 2 \mathrm{msec})$ delivered at two different frequencies (as marked). Data points represent means \pm SDs of measurements from four to six cells. 
responses. Indeed, GABA is perhaps the most ubiquitous inhibitory transmitter in the nervous system, and G-protein-coupled $\mathrm{GABA}_{\mathrm{B}}$ receptors are potent presynaptic regulators of exocytotic $\mathrm{Ca}^{2+}$ channels and transmitter release (Davies, 1981; Dittman and Regehr, 1996, Takahashi et al., 1998). The fact that all of the same inhibitory machinery is present in neuronal somata strongly implies that $\mathrm{Ca}^{2+}$-dependent processes in addition to exocytosis undergo similar regulation by $\mathrm{GABA}_{\mathrm{B}}$ and other G-proteincoupled receptors.

Our data show that, under normal physiological conditions, the combined effects of modulatory transmitters such as GABA and $\mathrm{NE}$ can vary widely, depending on the excitability of the cell, the exact shape and amplitude of the APW, the presence or absence of tonic AP activity, and the properties of the effector response under study. In cases in which $\mathrm{Ca}^{2+}$ current density is high enough to influence action potential shape (in neuronal somata), the net effect of transmitter on $\mathrm{Ca}^{2+}$ entry can be difficult to predict. Reductions in the rate and amplitude of $\mathrm{Ca}^{2+}$ entry by transmitters and G-proteins, for example, might be partially offset if the transmitter reduces action potential duration (Dunlap and Fischbach, 1978), because shorter-duration action potentials evoke larger and faster $\mathrm{Ca}^{2+}$ currents (Fig. 7). Furthermore, as shown here and elsewhere (Womack and McClesky, 1995; Brody et al., 1997; Williams et al., 1997), frequency-dependent relief of transmitter and G-protein inhibition of $\mathrm{Ca}^{2+}$ channels offers an additional mechanism by which the rate of change of intracellular $\mathrm{Ca}^{2+}$ can be controlled.

Not all studies of G-protein-mediated $\mathrm{Ca}^{2+}$ channel inhibition have demonstrated frequency-dependent changes in modulation (Toth and Miller, 1995). Although the reasons for this are not entirely clear, experimental variability would be anticipated. Our results demonstrate that $\mathrm{Ca}^{2+}$ influx is a complex function of many, interacting parameters, which will undoubtedly vary among preparations. Variations in the complement of ion channels are common, leading to differences in action potential shape and frequency-dependent effects on APW. In addition, different $\mathrm{Ca}^{2+}$ channel types exhibit a variety of biophysical properties (e.g., voltage-dependent gating and inactivation) and respond differentially to both changes in voltage and G-protein activation (Dolphin, 1995; Tsien et al., 1995; Jones and Elmslie, 1997). Finally, the issue of temperature must be considered, as both the gating and modulation of $\mathrm{Ca}^{2+}$ channels are steep functions of temperature (McAllister-Williams and Kelly, 1995a,b; Sabatini and Regehr, 1996). Thus, the precise conditions necessary to bring about frequency-dependent facilitation in one preparation might lead to depression of $\mathrm{Ca}^{2+}$ influx in another preparation expressing different $\mathrm{Ca}^{2+}$ channels, modulatory pathways, or effector molecules.

Even in the absence of a changing molecular environment, the modulation of synaptic transmission at individual synapses can show a complex response to changes in firing frequency and/or G-protein activation. The synapse between auditory nerve fibers and cells in the nucleus magnocellularis in the chick is a good example of such a synapse. High-frequency firing rates at which these neurons normally function promote rapid synaptic depression (Trussell et al., 1993). By presynaptically inhibiting transmitter release, GABA slows the rate of synaptic depression, paradoxically prolonging transmission and extending the dynamic range over which the synapse functions (Brenowitz et al., 1998). Thus, GABA inhibits low-frequency transmission and facilitates high-frequency transmission at this synapse.

Taken together, the interactions between the biophysical and biochemical mechanisms regulating $\mathrm{Ca}^{2+}$ channels offer sufficient complexity to precisely tailor $\mathrm{Ca}^{2+}$ influx in a changing physiological environment. Future experiments must explore the consequences of such modulation for enzyme activation, gene transcription, membrane excitability, exocytosis, and other cellular responses that are sensitive to changes in intracellular $\mathrm{Ca}^{2+}$.

\section{REFERENCES}

Aldrich RW, Getting PA, Thompson SH (1979) Mechanism of frequency-dependent broadening of molluscan neurone soma spikes. J Physiol (Lond) 291:531-544.

Aosaki T, Kasai H (1989) Characterization of two kinds of high-voltageactivated $\mathrm{Ca}$-channel currents in chick sensory neurons. Pflügers Arch 414:150-156.

Bean BP (1989) Neurotransmitter inhibition of neuronal calcium currents by changes in channel voltage dependence. Nature 340:153-156.

Brenowitz S, David J, Trussell L (1998) Enhancement of synaptic efficacy by presynaptic $\mathrm{GABA}_{\mathrm{B}}$ receptors. Neuron 20:135-141.

Brody DL, Patil PG, Mulle JG, Snutch TP, Yue DT (1997) Bursts of action potential waveforms relieve G-protein inhibition of recombinant P/Q-type $\mathrm{Ca}^{2+}$ in HEK 293 cells. J Physiol (Lond) 499:637-644.

Carbone E, Lux HD (1984) A low voltage-activated, fully inactivating Ca channel in vertebrate sensory neurons. Nature 310:501-502.

Chalazonitis A, Peterson ER, Crain SM (1987) Nerve growth factor regulates the action potential duration of mature sensory neurons. Proc Natl Acad Sci USA 84:289-293.

Cox DH, Dunlap K (1992) Pharmacological discrimination of N-type from L-type calcium current and its selective modulation by transmitters. J Neurosci 12:906-914.

Davies J (1981) Selective depression of synaptic excitation in cat spinal neurones by baclofen: an iontophoretic study. $\mathrm{Br} \mathrm{J}$ Pharmacol 72:373-384

De Konninck P, Schulman H (1998) Sensitivity of CaM Kinase II to the frequency of $\mathrm{Ca}^{2+}$ oscillations. Science 279:227-230.

Dittman JS, Regehr WG (1996) Contributions of calcium-dependent and calcium-independent mechanisms to presynaptic inhibition at a cerebellar synapse. J Neurosci 16:1623-1633.

Diversé-Pierluissi M, Dunlap K (1993) Distinct, convergent second messenger systems modulate neuronal calcium currents. Neuron 10:753-760.

Diversé-Pierluissi M, Goldsmith PK, Dunlap K (1995) Transmittermediated inhibition of N-type calcium channels in sensory neurons involves multiple GTP-binding proteins and subunits. Neuron 14:191-200.

Diversé-Pierluissi M, Remmers AE, Neubig RR, Dunlap K (1997) Novel form of crosstalk between G-protein and tyrosine kinase pathways. Proc Natl Acad Sci USA 94:5417-5421.

Dolmetsch RE, Lewis RS, Goodnow CC, Healy JI (1997) Differential activation of transcription factors induced by $\mathrm{Ca}^{2+}$ response amplitude and duration. Nature 386:855-858.

Dolphin AC (1995) Voltage-dependent calcium channels and their modulation by neurotransmitters and G-proteins. Exp Physiol 80:1-36.

Dunlap K, Fischbach GD (1978) Neurotransmitters decrease the calcium component of sensory neurone action potentials. Nature 276:837-839.

Dunlap K, Ikeda SR (1998) Receptor-mediated pathways that modulate calcium channels. Semin Neurosci 9:198-208.

Elmslie KS, Zhou W, Jones SW (1990) LHRH and GTP $\gamma$ S modify calcium current activation in bullfrog sympathetic neurons. Neuron 5:75-80.

Fields RD, Eshete F, Stevens B, Itoh K (1997) Action potentialdependent regulation of gene expression: temporal specificity in $\mathrm{Ca}^{2+}$, cAMP-responsive element binding proteins, and mitogen-activated protein kinase signaling. J Neurosci 17:7252-7266.

Fitzgerald M (1987) Cutaneous primary afferent properties in the hind limb of the neonatal rat. J Physiol (Lond) 383:79-92.

Fox AP, Nowycky MC, Tsien RW (1987) Kinetic and pharmacological properties distinguishing three types of calcium currents in chick sensory neurones. J Physiol (Lond) 394:140-172.

Gage PW (1992) Activation and modulation of neuronal $\mathrm{K}^{+}$channels by GABA. Trends Neurosci 15:46-51.

Gao T, Puri TS, Gerhardstein BL, Chien AJ, Green RD, Hosey MM (1997) Identification and subcellular localization of the subunits of 
L-type calcium channels and adenylyl cyclase in cardiac myocytes. J Biol Chem 272:19401-19407.

Ghosh A, Ginty DD, Bading H, Greenberg ME (1994) Calcium regulation of gene expression in neuronal cells. J Neurobiol 25:294-303.

Grassi F, Lux HD (1989) Voltage-dependent GABA-induced modulation of calcium currents in chick sensory neurons. Neurosci Lett 105:113-119.

Gu X, Spitzer NC (1995) Distinct aspects of neuronal differentiation encoded by frequency of spontaneous $\mathrm{Ca}^{2+}$ transients. Nature 375:784-787.

Hamill OP, Marty A, Neher E, Sakmann B, Sigworth FJ (1981) Improved patch-clamp techniques for high resolution current recording from cells and cell-free membrane patches. Pflügers Arch 391:85-100.

Haydon PG, Henderson E, Stanley EF (1994) Localization of individual calcium channels at the release face of a presynaptic nerve terminal. Neuron 13:1275-1280.

Hsu SF, Augustine GJ, Jackson MB (1996) Adaptation of $\mathrm{Ca}^{2+}$ triggered exocytosis in presynaptic terminals. Neuron 17:501-512.

Ikeda SR, Dunlap K (1998) Voltage-dependent modulation of N-type calcium channels: role of G-protein subunits. Adv Second Messenger Phosphoprotein Res, in press.

Jackson MB, Konnerth A, Augustine GJ (1991) Action potential broadening and frequency-dependent facilitation of calcium signals in pituitary nerve terminals. Proc Natl Acad Sci USA 88:380-384.

Jones LP, Patil PG, Snutch TP, Yue DT (1997) G-protein modulation of N-type calcium channel gating current in human embryonic kidney cells (HEK 293). J Physiol (Lond) 498:601-610.

Jones SW, Elmslie KS (1997) Transmitter modulation of neuronal calcium channels. J Membr Biol 155:1-10.

Jorgensen AO, Shen AC, Arnold W, Leung AT, Campbell KP (1989) Subcellular distribution of the 1,4-dihydropyridine receptor in rabbit skeletal muscle in situ: an immunofluorescence and immunocolloidal gold-labeling study. J Cell Biol 109:135-147.

Koerber HR, Mimics K, Mendell LM (1995) Properties of regenerated primary afferents and their functional connections. J Neurophysiol 73:693-702.

Llinas R, Sugimori M, Simon SM (1982) Transmission by presynaptic spike-like depolarization in the squid giant synapse. Proc Natl Acad Sci USA 79:2415-2419.

Luebke JI, Dunlap K (1994) Sensory neuron N-type calcium currents are inhibited by both voltage-dependent and -independent mechanisms. Pflügers Arch 428:499-507.

Ma M, Koester J (1996) The role of $\mathrm{K}^{+}$currents in frequencydependent spike broadening in Aplysia R20 neurons: a dynamic-clamp analysis. J Neurosci 16:4089-4101.

McAllister-Williams RH, Kelly JS (1995a) The temperature dependence of high threshold calcium channel currents recorded from adult raphe neurones. Neuropharmacology 34:1479-1490.

McAllister-Williams RH, Kelly JS (1995b) The modulation of calcium currents recorded from adult rat dorsal raphe neurones by 5HT1A receptor or direct G-protein activation. Neuropharmacology 34:1491506 .

McCobb DP, Beam KC (1991) Action potential waveform voltage-clamp commands reveal striking differences in calcium entry via low and high voltage-activated calcium channels. Neuron 7:119-127.

Mintz IM, Adams ME, Bean BP (1992) P-type calcium channels in rat central and peripheral neurons. Neuron 9:85-95.

Narahashi T, Tsunoo A, Yoshi M (1987) Characterization of two types of calcium channels in mouse neuroblastoma cells. J Physiol (Lond) 383:231-249.

Patil PG, Brody DL, Yue DT (1998) Preferential closed-state inactivation of neuronal calcium channels. Neuron, 20:1027-1038.

Robitaille R, Adler EM, Charlton MP (1990) Strategic location of calcium channels at transmitter release sites of frog neuromuscular synapses. Neuron 5:773-779.

Sabatini BL Regehr WG (1996) Timing of neurotransmission at fast synapses in the mammalian brain. Nature 384:170-172.

Spencer AN, Przysiezniak J, Acosta-Urquidi J, Basarsky TA (1989) Presynaptic spike broadening reduces junctional potential amplitude. Nature 340:636-638.

Spitzer N (1984) Development of voltage-dependent and ligand-gated channels in excitable membranes. Prog Brain Res 102:169-179.

Takahasi T, Kajikawa Y, Tsujimoto T (1998) G-protein-coupled modulation of presynaptic calcium currents and transmitter release by a $\mathrm{GABA}_{\mathrm{B}}$ receptor. J Neurosci 18:3138-3146.

Toth PT, Miller RJ (1995) Calcium and sodium currents evoked by action potential waveforms in rat sympathetic neurones. J Physiol (Lond) 485:43-57.

Triggle DJ, Janis RA (1987) Calcium channel ligands. Annu Rev Pharmacol Toxicol 27:347-369.

Trussell LO, Zhang S, Raman IM (1993) Desensitization of AMPA receptors upon multiquantal neurotransmitter release. Neuron 10:1185-1196.

Tsien RW, Lipscombe D, Madison D, Bley K, Fox A (1995) Reflections on $\mathrm{Ca}^{2+}$-channel diversity, 1988-1994. Trends Neurosci 18:52-54.

Williams S, Serafin M, Muhlethaler M, Bernheim L (1997) Facilitation of N-type calcium current is dependent on the frequency of action potential-like depolarization in dissociated cholinergic basal forebrain neurons of the guinea pig. J Neurosci 17:1625-1632.

Womack MD, McClesky EW (1995) Interaction of opioids and membrane potential to modulate $\mathrm{Ca}^{2+}$ channels in rat dorsal root ganglion neurons. J Neurophysiol 73:1793-1798. 